\title{
Development of Chemo-Entrepreneurship Oriented Learning Design Based on Green Chemistry
}

\author{
Umi Setyaningsih $^{1 凶}$, Sri Susilogati Sumarti ${ }^{2}$, Sudarmin $^{2}$ \\ ${ }^{1}$ SMK Negeri 1 Sayung, Indonesia \\ ${ }^{2}$ Pascasarjana, Universitas Negeri Semarang, Indonesia
}

\begin{tabular}{|c|c|}
\hline Article Info & Abstract \\
\hline $\begin{array}{l}\text { Article History : } \\
\text { Received February } 2020 \\
\text { Accepted March } 2020 \\
\text { Published April } 2021\end{array}$ & \multirow{3}{*}{$\begin{array}{l}\text { This research aims to produce a valid and effective learning device for chemo- } \\
\text { entrepreneurship-based projects that are valid and positive student responses. } \\
\text { This research includes development research adopted from Thiagarajan, a } \\
\text { modified } 4 \mathrm{D} \text { model. The } 4 \text {-D model consists of four stages of development, } \\
\text { namely Define, Design, Develop, and Disseminate. Disseminate stage is not } \\
\text { done because the Develop phase has produced a valid learning device. The } \\
\text { validity assessment of learning devices was carried out by four experts. } \\
\text { Instrument for assessing learning devices are syllabus components, lesson } \\
\text { plan, teaching materials, project work sheets. The effectiveness of learning } \\
\text { devices is seen from improving student learning outcomes. Based on the } \\
\text { results of the analysis obtained a validity value of } 3,59 \text { ( } 88,5 \% \text { ) with a very } \\
\text { good category. Entrepreneurial interest in the extensive trial shows that the } \\
\text { results of the paired sample t-test obtained a } t_{\text {count }}=19,981 \text { and t table }=2,03 \text {. } \\
\mathrm{T}_{\text {count }}>\mathrm{t} \text { table which means there is a significant increase in student interest. } \\
\text { Based on the results of the assessment, the learning devices of the chemo- } \\
\text { entrepreneurship-based green chemistry-based clean project can be said to be } \\
\text { valid and effective for learning. }\end{array}$} \\
\hline $\begin{array}{l}\text { Learning Media, Project } \\
\text { Based Learning, Chemo- } \\
\text { Entreprenuership, Green } \\
\text { Chemistry }\end{array}$ & \\
\hline & \\
\hline
\end{tabular}

$\square$ correspondence :

SMK Negeri 1 Sayung, Indonesia

Jalan Raya Semarang Demak Km 14 Onggorawe Sayung Demak,

Daleman, Tugu, Kec. Sayung, Kabupaten Demak, Jawa Tengah 59563

E-mail: UmiSetyaningsih49@yahoo.com 


\section{INTRODUCTION}

Quality of Human Resources (HR) are highly demanded in the current development. Indonesia's competitiveness in facing competition between countries including in free trade is determined from the results of its human resource development. The quality of human resources is closely related to the level of education. Based on Central Bureau of Statistics data in February 2016, the number of unemployed in Indonesia is dominated by high school and vocational school graduates. The contribution of Vocational High School (VHS) to the number of unemployed in Indonesia is partly due to the lower special skills or soft skills of VHS compared to high school graduates. The implementation of education in Vocational Schools must be in accordance with Law No. 20 of 2003 concerning the National Education System, it is explained that vocational education is secondary education which prepares students especially to work in certain fields of vocational education consisting of Vocational High Schools, and Madrasah Aliyah Vocational. The 2013 curriculum is an effort to simplify the curriculum that is prepared to produce generations in facing future challenges. The results of research conducted by Rezeki et al. (2015) show that students have a much better, more creative, innovative and productive attitude, skill and knowledge competency through the 2013 curriculum so that they can face various future challenges. Students are encouraged to apply the concepts they learn in solving problems encountered in everyday life. Chemistry subjects were given specifically in Demak district according to the Subject Teacher Deliberations chemistry agreement and in it was added colloidal material. The reason is because chemical materials are very important and are needed for the provision of vocational students if they have entered the world of industry or in society.

Colloidal material is an important subject taught to students because the material is very contextual, studying the phenomena of material changes that exist in nature (Sumarti et al., 2014). The current learning curriculum uses the 2013 curriculum which emphasizes scientific learning. Innovative and creative learning can stimulate students to be more independent, creative, and quality (Sudarmin, 2015). One of the scientific learning models that can be applied at SMK is Project Based Learning (PBL) or project learning. The project-based learning model is a learning model that uses real world problems as a context for students to learn about critical thinking and problem solving skills, as well as to obtain essential knowledge and concepts from learning material. This learning makes students able to design and create a project that they want based on the knowledge, information and skills they have. Project learning trains vocational students in creating a product. Students are expected to be able to practice sotf skills and hard skills.

Chemo-entrepreneurship is one of the learning approaches related to life skills (Prayitno $e t$ al., 2017). Entrepreneurship-oriented learning can be linked in aspects of knowledge, psychomotor, and affective (Carnawi et al., 2017). This is what is demanded in the competitive world of work. This skill is also very useful for students who want to become an entrepreneur (entrepreneur). The number of entrepreneurs created is expected to be able to drive the country's economic progress. Learning with the Chemo-entrepreneurship approach is connected directly to students so that learning chemistry becomes easily understood (Drastisianti et al., 2018). The application of chemoentrepreneurship will be applied optimally to the learning process with the help of teaching materials (Triawan et al., 2017). Chemo-entrepreneurshiporiented learning can be included in teaching materials so as to increase cognitive, psychomotor, and affective knowledge in learning. Chemoentrepreneurship learning can be included in teaching materials so as to increase cognitive, psychomotor, and affective knowledge in learning. Chemo-entrepreneurship learning is contextual learning that links subject matter with real objects in life, hoping that students will more easily understand chemistry that tends to be abstract (Sunarya et al., 2018). To realize interesting chemistry learning and foster student creativity and innovation, one of them is through chemoentrepreneurship-oriented learning approaches (Wibowo \& Ariyatun, 2018). CEP learning is aligned with learning characteristics because it makes chemistry lessons more applicable and equips students' soft skills (Zammi \& Khoiriyyah, 2018). 
The concept of green chemistry approach can be the right choice to be integrated into current chemistry learning which is expected to be meaningful and relevant to environmental conditions. This concept can represent a reflection of a continuing education process. (Saptorini, 2014) states that in practice the application of green chemistry approach is based on 12 principles of green chemistry. Chemistry learning, which is oriented towards green chemistry, brings students directly involved with the environment in their learning activities (Afiyanti et al., 2014). Green chemistry which plays a role in the preservation of human life and the environment can be applied in chemistry learning.

Learning in schools starts from the planning process, the implementation of teaching and learning activities, and evaluating student learning outcomes that aim to determine learning achievement. The planning stage consists of making teaching administration including syllabus, lesson plans, teaching materials, evaluation tools and other learning tools.

Student entrepreneurial interest can be increased through education by instilling entrepreneurial education into all subjects, teaching materials, extracurricular, and self-development. The chemo-entrepreneurship-oriented project learning model based on green chemistry is expected to improve student learning outcomes and foster entrepreneurial interest. Students after graduation are expected to face existing problems by applying the knowledge or skills they have acquired by paying attention to the application of green chemistry in the environment.

\section{METHODS}

The learning device development model used is a 4-D model which includes; define, design, develope and disseminate. In this study a modification of the 4-D model is simplified from four stages to three stages, namely define, design, and develop. Disseminate (dissemination) was not carried out due to time considerations but carried out the implementation of models in the field that are expected to have a positive impact.

Development research is a research method used to produce certain products and test the effectiveness of these products (Sugiyono, 2013:
407). The product in this study is a learning tool developed in the form of syllabus and lesson plans with a chemo-entrepreneurship oriented learning model based on green chemistry, teaching materials, assignment sheets, observation sheets and student assessment sheets. Products developed using this modified 4D model are tested for validity and effectiveness are Chemo-entrepreneurship oriented learning projects based on green chemistry.

The trial design will be carried out on grade $\mathrm{X}$ students in the even semester at Vocational High School 1 Sayung Demak. Small-scale trial subjects were 15 students from class X TSM1, while for large-scale trials were class 36 students of TSM2 and implementation were class X TL1 and X TL2, amounting to 72 people. This research focuses on developing a valid and effective chemoentrepreneurship oriented learning chemistry-based project design. Indicators of the success of this study are: 1) this device is declared valid if the average value is in the range of $3,00 \leq n \leq 4,00 ; 2$ ) this device is declared effective if: a) the average cognitive score of students $\geq 75$ with a classical completeness of $75 \%$; b) affective learning outcomes of students achieve mastery if the average is good with a minimum value of 2,$50 ; 2$ ) psychomotor learning outcomes of students achieve mastery if the average is good with a minimum grade of 2,50 . The steps in this development include the define stage which consists of syllabus analysis, students, material, assignments, teaching materials and formulation of learning objectives. The design phase is to design a product with characteristics that have been analyzed at the define stage. And finally the development stage by validating the learning tools and teaching materials. Furthermore, the product will be tested on limited classes and large scale classes. In the large-scale trial aspects aspects measured were cognitive aspects in the form of mastery of concepts, psychomotor aspects in the form of project observations, product evaluations, and affective aspects focused only on student responses.

\section{RESULTS AND DISCUSSION}

\section{Research Instrument Validation Results}

The initial product development (draft I) was validated by four validators. Validation is carried out on (1) teaching material, which consists of 
material assessment and readability assessment, (2) syllabus, (3) lesson plans, (4) questionnaire responses, (5) cognitive test questions, (6) observation sheets for affective aspects assessment, and (7) observation sheet for evaluation of psychomotor aspects. The recapitulation of the results of the validation of the research instruments is presented in Table 1.

Table 1. Summary of Expert Validation Results for Learning Tools

\begin{tabular}{llllllll}
\hline \multirow{2}{*}{ Learning Media } & \multicolumn{4}{l}{ Validator Rating } & Average & Score/Criteria \\
\cline { 2 - 5 } \cline { 2 - 5 } & V1 & V2 & V3 & V4 & & \\
\hline Syllabus & 3.4 & 3.5 & 3.6 & 3.3 & 3.45 & \\
Lesson plan & 3.85 & 3.7 & 3.75 & 3.45 & 3.7 & 3.59 \\
Teaching materials & 3.7 & 3.8 & 3.7 & 3.3 & 3.6 & (Valid) \\
Project worksheet & 3.7 & 3.9 & 3.75 & 3.2 & 3.6 & \\
\hline
\end{tabular}

Based on the results listed in Table 1, it can be concluded that all research instruments have valid criteria. Development of devices is arranged by developing all the learning tools needed in learning. The tools developed include the syllabus, lesson plans, teaching materials, and project worksheets. The syllabus is used to refer to a curriculum development product in the form of further elaboration of competency standards and basic abilities to be achieved, and the main points and descriptions of material that students need to learn in achieving basic competency and competency standards (Susetya, 2017). The syllabus development has been carried out by researchers, with the existence of a Subject Teacher Deliberations Chemistry agreement in Demak Regency. Colloidal material which has many applications in daily life, added in the syllabus. The syllabus is validated by the validator. This validator consists of experts or expert lecturers. The results of validator $1=3,4$, validator $2=3,5$, validator $3=$ 3,6 , validator $4=3,7$. The results of the validation show that the syllabus, learning implementation plan, teaching materials, and green chemistry-based entrepreneurship-oriented project worksheets that have been developed are valid and effective for use.

\section{Discussion of Student Learning Outcomes}

Students' understanding of the material can be seen from the results of the pre-test and post-test conducted. Pretests and post tests are conducted in the form of multiple-choice questions. If student learning outcomes exceed Minimal completeness criteria then it can be said the student learning outcomes are complete. Small-scale trials carried out in class X Motorcycle Engineering (ME)1, large-scale trials X Motorcycle Engineering (ME)2.

a. The SPSS student completeness test data are presented in Table 2.

Table 2. Students' Mastery Test Results

One-Sample Test

\begin{tabular}{lllllll}
\hline \multicolumn{9}{c}{\begin{tabular}{l}
\multicolumn{3}{l}{ Test Value $=75$} \\
Learning outcomes \\
(Post Test)
\end{tabular}} & $\mathrm{T}$ & df & Sig. (2-tailed) & $\begin{array}{l}\text { Mean } \\
\text { Difference }\end{array}$ & \multicolumn{2}{l}{$\begin{array}{l}\text { 95\% Confidence Interval of the Difference } \\
\text { Lower }\end{array}$} & Upper \\
\cline { 2 - 7 } & 8.840 & 35 & 0.000 & 14.583 & 11.23 & 17.93 \\
\hline
\end{tabular}

The cognitive learning completeness test results obtained $t_{\text {count }}=8,840$ with a significance value of 0,000 . At the error level of $5 \%$ with $\mathrm{dk}=36$ $-1=35$, a table $=2,03$ is obtained. $\mathrm{T}_{\text {count }}>$ ttable which means that students' cognitive learning outcomes have exceeded Minimum completeness criteria $=75$ or achieved mastery learning.
b. Analysis of Student Learning Outcomes Improvement

Analysis of the results of student learning improvement to determine the success of learning colloidal material that has been obtained by students. Student learning outcomes are based on pre-test and post-test results which are then processed and analyzed to determine the increase or effectiveness of the given colloidal material. The results of tests of learning improvement or effectiveness are presented in Table 3. 
Table 3. Student Learning Improvement Test Results

Paired Samples Test

Paired Differences

\begin{tabular}{|c|c|c|c|c|c|c|c|c|c|}
\hline \multirow[b]{3}{*}{ Pair 1} & \multirow[b]{3}{*}{$\begin{array}{l}\text { Pre_Test - Hasil } \\
\text { Belajar (Post Test) }\end{array}$} & \multirow[t]{2}{*}{ Mean } & \multirow{2}{*}{$\begin{array}{l}\text { Std. } \\
\text { Deviation }\end{array}$} & \multirow{2}{*}{$\begin{array}{l}\text { Std. Error } \\
\text { Mean }\end{array}$} & \multicolumn{2}{|c|}{$\begin{array}{l}95 \% \text { Confidence Interval } \\
\text { of the Difference }\end{array}$} & \multirow[t]{2}{*}{$\mathrm{t}$} & \multirow[t]{2}{*}{$\mathrm{df}$} & \multirow[t]{2}{*}{$\begin{array}{l}\text { Sig. (2- } \\
\text { tailed) }\end{array}$} \\
\hline & & & & & Lower & Upper & & & \\
\hline & & 57.917 & 17.620 & 2.937 & 63.879 & 51.955 & 19.721 & 35 & 0.000 \\
\hline
\end{tabular}

Paired sample t-test test results obtained $t_{\text {count }}$ $=19,721$ with a significance value of 0,000 . At the error level of $5 \%$ with $\mathrm{dk}=36-1=35$, a table $=$ 2,03 is obtained. $\mathrm{T}_{\text {count }}>$ ttable which means there is a significant increase in learning outcomes. Apart from the $t_{\text {count, }}$, it can be seen from the difference in the mean value obtained at 57,917 which shows that an increase in the pre-test and post-test. This shows that the learning of colloidal material has been successfully carried out or has been effectively given colloidal material so that students feel able to do it. c. Discussion of Entrepreneurial Interests and Student Responses

1) Student entrepreneurial interest

Similar to small- and large-scale trials, in this implementation. Data on students' entrepreneurial interest is obtained from questionnaires filled out by students before and after learning. Data on interest in implementation can be seen in Figure 2.

Based on the analysis conducted through the SPSS program, the results of the paired sample t-test obtained a $t_{\text {count }}=28,475$ with a significance value of 0,000 . At the error level of $5 \%$ with $\mathrm{dk}=72-1=$ 71 , obtained $t_{\text {table }}=1,99 . T_{\text {count }}>$ ttable which means there is a significant increase in student interest.

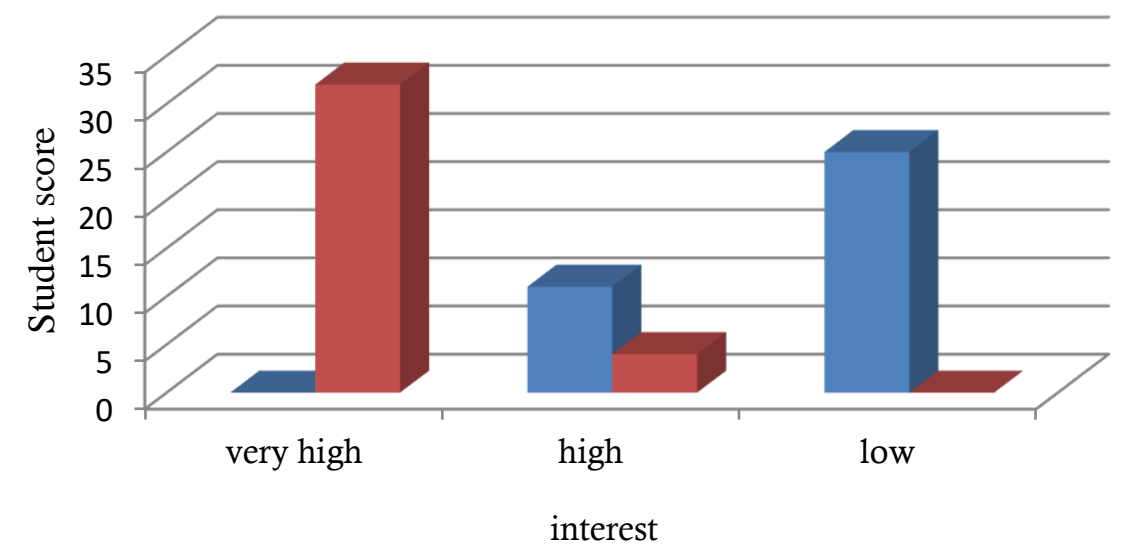

Figure 1. Results of Entrepreneurial Interest Questionnaire before and after Learning

Education often focuses on developing knowledge and intellect, while entrepreneurship education focuses on humans as a whole (including their feelings, values and interests) including creative and innovative ways of thinking (Wibowo, 2017). Chemistry-oriented entrepreneurship education based on green chemistry on colloidal material chemistry subjects can improve student learning.

2) Results of Student Response Analysis

Data on student responses to learning chemoentrepreneurship oriented projects based on green chemistry at the complete implementation stage can be seen in appendix 30. Student responses to implementation can be seen in Figure 6. 


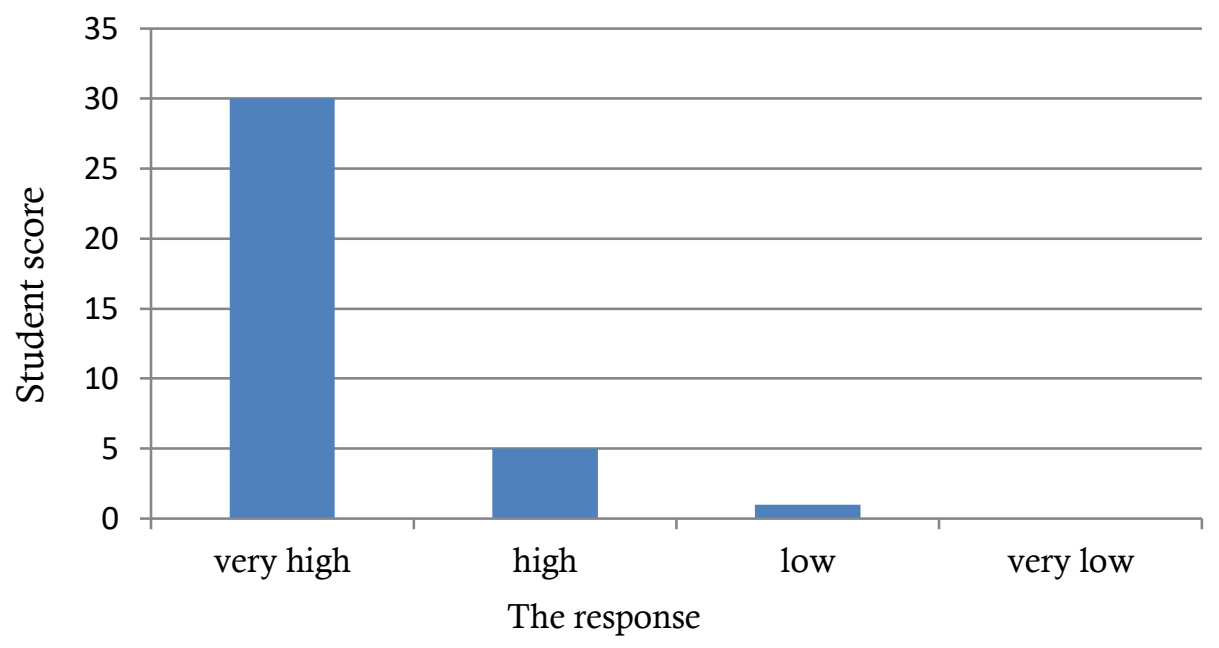

Figure 2. Student responses to the Chemo-entrepreneurship Oriented Project Design Based on Green

Chemistry

The effectiveness of the developed learning model can be seen from students' responses to learning. The results of student responses can be seen from the results of a questionnaire that has been filled out by students after participating in the learning process. The results of the analysis show students have a positive response, so it can be said that the instrument developed and given to these students is an instrument that can be accepted and has a positive value to the learning design of chemistry-entrepreneurship oriented projects based on green chemistry

\section{CONCLUSION}

Based on the results of the data analysis it can be concluded as follows: Chemo-entrepreneurshiporiented project learning tools based on Green Chemistry meet valid criteria with a value of 3,75 . All students in the implementation have achieved values above the completeness criteria so that the Chemo-entrepreneurship oriented project based on Green Chemistry can be said to improve student learning outcomes. Student's entrepreneurial interest in the broad trial phase shows the results of the paired sample $t$-test obtained $t_{\text {count }}=19,981$ and $t_{\text {table }}=2,03 . \quad T_{\text {count }}>t_{\text {table }}$ which means there is a significant increase in students' interest. While at the implementation stage the paired sample t-test test results obtained tcount $=28,475$ and $t_{\text {table }}=$ 1,99 . $T_{\text {count }}>$ ttable which means there is a significant increase in students' interest. Students give a positive response to the learning design of Chemo- entrepreneurship oriented projects based on Green Chemistry

\section{REFERENCES}

Afiyanti, N. A., Cahyono, E., \& Soeprodjo. (2015). Keefektifan Inkuiri Terbimbing Berorientasi Green Chemistry terhadap Keterampilan Proses Sains. Jurnal Inovasi Pendidikan Kimia, 8(1), 12811288.

Carnawi, Sudarmin, \& Wijayanti, N. (2017). Application of Project Based Learning ( PBL ) Model for Materials of Salt Hydrolysis to Encourage Students' Entrepreneurship Behaviour. International Journal of Active Learning, 2(1), 50-58.

Drastisianti, A., Susilaningsih, E., Supartono, M., \& Wijayati, N. (2018). The Study of Chemistry Learning on The Material of Buffer Solution Supported by Teaching Material of Multiple Representation-Chemoentrepreneurship Viewed From Student Entrepreneurship Interest. Advances in Social Science, Education and Humanities Research (ASSEHR), 247(3), 27-31.

Prayitno, M. A., Wjayanti, N., \& Mursiti, S. (2017). Penerapan Modul Kimia Berpendekatan Chemoentrepreneurship untuk Meningkatkan Kecakapan Hidup dan Motivasi Belajar. Journal of Innovative Science Education (JISE), 6(2), 139 - 146.

Rezeki, R., Nurhayati, N., \& Mulyani, S. (2015). Penerapan Metode Pembelajaran Project Based Learning ( $\mathrm{PjBL}$ ) disertai dengan Peta Konsep untuk Meningkatkan Prestasi dan Aktivitas Belajar Siswa pada Materi Redoks Kelas X-3 SMA Negeri Kebakkramat Tahun Pelajaran 2013 / 2014. Jurnal Pendidikan Kimia Universitas Sebelas Maret, 4(1), 74-81. 
Sudarmin. (2015). Model Pembelajaran Inovatif Kreatif. Semarang: Fakutas FMIPA Unnes.

Sugiyono. (2013). Penelitian Kualitatif, Kuantitatif, dan $R N D$. Bandung: Alfabeta.

Sumarti, S. S., Supartono, \& Diniy, H. H. (2014). Material Module Development of Colloid Orienting on Local-Advantage-Based ChemoEntrepreneurship to Improve Students' Soft Skill. International Humanities and Management Science, 2(1), 42-46.

Sunarya, R. A., Supartono, \& Sumarti, S. S. (2018). Analisis Hasil Belajar dan Minat Wirausaha Siswa Menggunakan Bahan Ajar Berorientasi Chemoentrepreneurship. Jurnal Inovasi Pendidikan Kimia, 12(1), 2065 - 2074.

Supartono, Saptorini, \& Asmorowati, D. S. (2011). Pembelajaran Kimia Menggunakan Kolaborasi Konstruktif dan Inkuiri Berorientasi ChemoEntrepreneurship. Jurnal Inovasi Pendidikan Kimia, 3(2), 476-483.

Susetya, B. (2017). Meningkatkan Kemampuan Guru dalam Menyusun Silabus dan RPP melalui
Supervisi Akademik di SD N Gambiran Yogyakarta Tahun 2016. Jurnal Taman Cendekia, 1(2), 1-14.

Triawan, S. A., Supardi, K. I., \& Wijayati, N. (2017). Pengembangan Chemistry Adventure Sheets Berorientasi Chemo-Entrepreneurship Terintegrasi Pendidikan Karakter. Lembaran Ilmu Kependidikan, 46(1), 60-67.

Wibowo, A. (2017). Dampak Pendidikan Kewirausahaan bagi Mahasiswa. Asian Journal of Entrepreneurship and Family Business, 1(1), 1-14.

Wibowo, T. \& Ariyatun, A. (2018). Penerapan Pembelajaran Berorientasi Chemoentrepreneurship (CEP) terhadap Kreativitas Siswa SMA Modern Pondok Selamat pada Materi Kelarutan dan Ksp. Jurnal Tadris Kimiya, 3(1), 62-72.

Zammi, M. \& Khoiriyyah, K. (2018). Analisis Kemampuan Soft Skills Siswa Kelas XI SMK Futuhiyyah Mranggen Demak. Phenomenon, 8(2), 154-164. 